\title{
Deep time travel
}

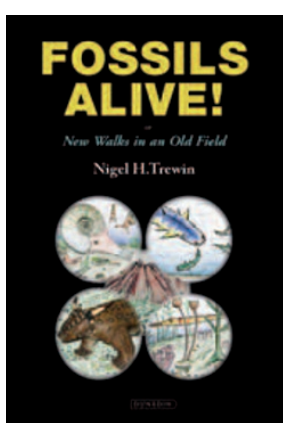

When I read Trewin's introduction, I was intrigued by the book's story line, invoking time travel in a bus to study prehistory. It brought to mind the book I used to read to my daughter: The Magic School Bus in the Time of the Dinosaurs by Joanna Cole (1995). After the first few pages, though, it was evident that Trewin has written a book that will very much appeal to the adult reader. He has chosen his favourite Scottish fossil localities, built a picture of each landscape and environment at the time when the fossils were living organisms, and brought us on a fact-filled adventure to prehistoric Scotland. We discover the delights of fossil collecting at these classic localities, and are entertained by the sounds, smells and feel of the living fossils from the Devonian to the Jurassic periods.

This book will appeal to the same audience that enjoy Hugh Miller, the famous nineteenth century natural history writer and popularizer of palaeontology who wrote The Old Red Sandstone, or New Walks in an Old Field (1841). Sir Roderick Impey Murchison, the director general of the British Geological Survey in the mid-nineteenth century, wrote that Miller's book "to a beginner, is worth a thousand didactic treatises". I believe that the same is true of Trewin's book. Trewin bases his knowledge on facts extracted from publications dating back over 150 years, as well as his own research into the Rhynie Chert, Devonian fishes, Carboniferous, Permian and Jurassic fossils, and the relevant palaeoenvironments. It is also apt that in their pursuit of palaeontological understanding, Miller and Trewin were both inspired by the fish fossils of the Devonian period found in the north of Scotland.
Although the book is structured chronologically from oldest to youngest, it was easy to dip into chapters on specific localities and later return to others. Each chapter stands on its own, with Trewin introducing the palaeontological site as it occurs in the present day, followed by a description of the fossil fauna and flora, and the environmental interpretations based on the evidence. Trewin then boards his field bus with a colleague and travels back in time to explore the nature of the environment, landscape and ecology of the same site when it first formed as per his interpretation of the facts. This is how real palaeontologists think, or at least how they ought to think: following the process from hard scientific fact, through the interpretation of facts and then letting imagination fill in the gaps.

The fossil sites come alive to our senses as Trewin takes his colleagues, and his readers, for a walk along the silent Devonian flood channels to look at the hot springs of Rhynie, to smell the stagnant pools of rotting fish of Dura Den, to run from Jurassic dinosaurs and to dive with ammonites and ichthyosaurs off the Isle of Skye.

Trewin's humour feeds the skilful narrative as he takes us on his challenging field excursions. He introduces many palaeontological concepts that are perhaps less familiar to the general scientific readership in a subtle yet powerful way. Field sketches and photographs help visualize the plants, animals and the various environments, and more than make up for the frustration of being unable to return to the present day with samples. Trewin leaves it to his readers to decide how much of the field trips to the past are supported by the facts, how much is "imagination fuelled by cider or a good malt whisky" and how much is based on speculative conversations with other scientists.

A common thread throughout the book is Trewin's love of fishing. At the same place in Caithness, he fishes for trout in the water-filled quarry and then travels back in time to catch the Devonian fish, Osteolepis. Which fly would be best to use in the Devonian? How big, in reality, was that 40-cm-long fish, Gyroptichius, that Trewin's colleague Jeremy caught? Perhaps his erudite storytelling comes from tales of his fishing exploits?

After surviving centipedes, geysers, dinosaurs and even a tsunami, Trewin ends on a philosophical note on conservation and the future of mankind. Those who think on a geological timescale will certainly relate to this. Evolution, extinctions and climate change are all part of our palaeontological and geological heritage. As Trewin speculates, we either become extinct, or we evolve.

Trewin's book is a great addition to popular science literature and will help to promote a better understanding of palaeontology. I hope that this is not Trewin's only book on Scottish fossil localities. I would like him to visit more of Scotland's rich fossil heritage and travel back in time, yet again - perhaps to the Ordovician trilobites of Girvan, the Silurian fishes of Lesmahagow, the Carboniferous sharks of Bearsden, or the Triassic reptiles of Arran?

Neil D. L. Clark

Neil D. L. Clark is at the Hunterian Museum of the University of Glasgow, Glasgow, G12 8QQ, UK. e-mail:n.clark@museum.gla.ac.uk 